The Cryosphere, 5, 81-93, 2011

www.the-cryosphere.net/5/81/2011/

doi:10.5194/tc-5-81-2011

(c) Author(s) 2011. CC Attribution 3.0 License.

\title{
First investigations of an ice core from Eisriesenwelt cave (Austria)
}

\author{
B. May ${ }^{1}$, C. Spötl ${ }^{2}$, D. Wagenbach ${ }^{1}$, Y. Dublyansky ${ }^{2}$, and J. Liebl ${ }^{3}$ \\ ${ }^{1}$ Institut für Umweltphysik, Universität Heidelberg, Im Neuenheimer Feld 229, 69120 Heidelberg, Germany \\ ${ }^{2}$ Institut für Geologie und Paläontologie, Lepold-Franzens-Universität Innsbruck, Innrain 52, 6020 Innsbruck, Austria \\ ${ }^{3}$ Vienna Environmental Research Accelerator (VERA), Fakultät für Physik - Isotopenforschung, Universität Wien, \\ Währinger Straße 17, 1090 Wien, Austria
}

Received: 13 August 2010 - Published in The Cryosphere Discuss.: 1 September 2010

Revised: 28 January 2011 - Accepted: 1 February 2011 - Published: 16 February 2011

\begin{abstract}
Investigations into the genesis and dynamical properties of cave ice are essential for assessing the climate significance of these underground glaciers. We drilled an ice core through a $7.1 \mathrm{~m}$-thick ice body filling a large cavern of the dynamic ice cave Eisenriesenwelt (Austria). In addition to visual core inspections, quasi-continuous measurements at $2 \mathrm{~cm}$ resolution comprised particulate matter, stable water isotope $\left(\delta^{18} \mathrm{O}, \delta \mathrm{D}\right)$ and electrolytic conductivity profiles supplemented by specifically selected samples analyzed for tritium and radiocarbon. We found that recent ablation led to an almost complete loss of bomb-derived tritium removing any ice accumulated since, at least, the early fifties leaving the actual ice surface even below the natural tritium level. The small particulate organic masses rendered radiocarbon dating inconclusive, though a crude estimate gave a basal ice age in the order of several thousand years. The visual stratigraphy and all investigated parameters showed a clear dichotomy between the upper $2 \mathrm{~m}$ and the bottom $3 \mathrm{~m}$ of the core, which points to a substantial change in the ice formation process. Main features of the core comprise the changing appearance and composition of distinct cryocalcite layers, extremely low total ion content and a surprisingly high variability of the isotope signature. Co-isotope evaluation $\left(\delta \mathrm{D}\right.$ versus $\delta^{18} \mathrm{O}$ ) of the core in comparison with data from precipitation and karst spring water clearly indicate that ice formation is governed by (slow) freezing of dripping water.
\end{abstract}

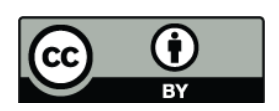

Correspondence to: B. May (barbara.may@iup.uni-heidelberg.de)

\section{Introduction}

In view of the current reduction of ice and permafrost areas in the European Alps and other mountains (Haeberli et al., 2004) exploration of historical climate changes at mid and low latitudes has become increasingly important. Next to non-temperated high-altitude glaciers underground ice bodies in caves might provide a useful climate archive (e.g. Luetscher, 2005). Particularly in view of their relatively low elevation and their possible specific seasonal significance these subsurface glaciers may constitute an important addition to sedimentary (surface) glaciers (Oerlemans, 2005) and other climate archives of the Alpine region, e.g. trees (Frank and Esper, 2005; Büntgen et al., 2006), lake sediments (von Grafenstein et al., 1999), and speleothems (Mangini et al., $2005,2007)$. If reasonably well dated, cave ice may offer useful climate proxy records, e.g. based on water isotopes or pollen. Moreover, of specific interest are periods of net ice accumulation which are likely driven by climate changes and which are marked by substantial gain, stagnation or loss of ice. Of prime importance in this context is constraining the maximum age of the ice body and dating the onset of its formation.

However, being very different from sedimentary surface glaciers, the origin and dynamics of cave ice are complex and not well understood. Cave ice generally accumulates by freezing of seepage water and to a lesser extent by condensation of moist air at sub-zero temperatures. As perennial cave ice does not only exist in areas where the annual mean temperature is below $0^{\circ} \mathrm{C}$, cooling of the cave system must be initiated by (winter) air circulation (e.g. Bock, 1913; Luetscher, 2005). For dynamic caves systems with two or more entrances at different elevations this is accomplished

Published by Copernicus Publications on behalf of the European Geosciences Union. 
by forced ventilation. Winter ventilation of the underground system is driven by the density difference of the cold outside and the relatively warm cave air. Chilling of (near-entrance) parts of such caves provides the cooling reservoir needed for freezing of infiltrating water.

Overall, the waxing and waning of perennial cave ice depends on many environmental parameters including the cave geometry, the outside climate and the lack or presence of winter snow cover providing infiltration water during spring snowmelt (Saar, 1956; Ohata, 1994a; Andreichuk and Dorofeev, 1994). Given this complexity it is not surprising that paleoclimate records based on cave ice are very scarce (Stoffel et al., 2009; Perşoiu et al., 2010), though ice caves exist in many regions of the world (e.g. the Alps, Canada, Romania, Japan, the Arctic). Holmlund et al. presented 2005 the first ice core study from the Scărişoara cave (Romania). However, until no,w the most comprehensive ice core study on cave ice has been performed in the static-dynamic Dobsina cave (Slovakia) by Vrana et al. (2007) and Clausen et al. (2007). On the other hand, observational studies focusing mainly on the spatial distribution of cave ice and its relation to meteorological conditions inside and outside the cave have been performed since several decades (e.g. Saar, 1956; Ohata et al., 1994b; Racoviţă and Onac, 2000).

A key area for this research are the Northern Calcareous Alps of Austria, which show the highest density of icebearing caves and which host some of the largest of their kind on Earth (Eisriesenwelt, Dachstein-Rieseneishöhle). Observations in some of these caves show a significant decadal to centennial-scale variability in ice volume (e.g. Behm et al., 2009) and a decrease in ice mass over recent decades in many but not all sites (Saar, 1956; Pavuza and Mais, 1999; Mais and Pavuza, 2000; Wimmer, 2008; Pavuza, 2010). Only few studies worldwide, however, concentrated on the physical processes of cave-ice formation as a combination of coupled energy and mass balance (including solid rock, air, liquid water and ice; Ohata, 1994a, b; Obleitner and Spötl, 2010). The processes related to changes in the stable water isotope composition of cave ice is even less known. Pavuza and Mais (1999) reported isotope $\left(\delta \mathrm{D}, \delta^{18} \mathrm{O}\right)$ values from alpine caves consistent with the meteoric water line with no indication of non-equilibrium fractionation. A similar consistency with the meteoric water line was recently identified by Kern et al. (2010) in the Mammuthöhle ice cave (Austria). In contrast, Yonge and MacDonald (1999) showed a significant isotopic difference between hoar frost and solid ice in Canadian ice caves and attributed this to fractionation processes between vapor and ice. Clausen et al. (2007) reported higher isotope values in Dobsina cave ice compared to local annual precipitation, and attributed this difference either to a seasonal bias of precipitation or changing evaporation conditions inside as well as outside of the cave.

Although several attempts have been made to date underground ice by radiocarbon $\left({ }^{14} \mathrm{C}\right)$ analyses of various organic carbon material back to ca. $2000 \mathrm{yr}$ BP (Achleitner,
1995; Dickfoss et al., 1997; Yonge and MacDonald, 1999; Pavuza and Spötl, 2000; Mais and Pavuza, 2000; Holmlund et al., 2005; Clausen et al., 2007; Luetscher et al., 2007) no straightforward method exists for establishing a detailed chronology of the ice accumulation.

In extending observational studies of ice distribution and cave meteorology of the Eisriesenwelt, which already started in the early 20th century (Lehmann, 1922; Hauser and Oedl, 1922, 1926), the project AUSTRO*ICE*CAVES*2100 combined meteorological, ice-mass balance, and ice characteristic studies in order to better understand the present-day relation between ice formation and climate settings. The ultimate goal of this project was to explore the possibility of extracting past climate records from alpine cave ice.

Here we present an overview on the first results gained from an ice core drilled to the base of the ice in the so-called Eispalast at the end of the ice-covered part in the Eisriesenwelt. Thereby, the chance for dating this ice body is explored and depth profiles of physical properties and water isotopes of the ice core are presented and discussed in terms of their (climate) implications.

\section{Setting, site selection, sampling and methods}

\subsection{Setting}

Eisriesenwelt, hereafter abbreviated as ERW, is a karst cave system with a large lower entrance at $1641 \mathrm{~m}$ a.s.l. (and a narrow second one at $1838 \mathrm{~m}$ ) and probably multiple upper openings, which are suspected (but as yet not identified) on the ca. 2200 m-high karst plateau of the Tennengebirge. ERW developed in the Upper Triassic Dachstein Limestone and shows an average rock overburden in its interior part of ca. $400-500 \mathrm{~m}$. Only the first ca. $1 \mathrm{~km}$ of this vast, about $40 \mathrm{~km}$-long cave system contains perennial ice commonly reaching a thickness of up to several meters and comprising a surface area of ca. $10000 \mathrm{~m}^{2}$ (Klappacher and HasekeKnapczyk, 1985). Within this frontal part the cave's longitudinal profile ascends from $1641 \mathrm{~m}$ at the entrance to $1775 \mathrm{~m}$ followed by a gradual decline toward the innermost icebearing parts (Fig. 1)

ERW is a dynamic ice cave and shows a classical bidirectional airflow pattern. During the warm season a strong draught reaching up to $10 \mathrm{~m} \mathrm{~s}^{-1}$ is felt at the lower entrance, while during winter cold outside air is drawn into the cave, slowly warms upon contact with the rock walls and ascends through unexplored shafts towards the plateau. During winter the $0^{\circ} \mathrm{C}$ isotherm progressively moves further into the cave and seasonal ice formations are locally present several hundred meters behind the perennial icebearing part. Detailed measurements performed within the AUSTRO*ICE*CAVES*2100 project show that this simple airflow pattern, however, is often disturbed (Obleitner and 
Spötl, 2010) underscoring the inherently unstable nature of such a dynamically ventilated cave.

Soon after ERW had been opened as a show cave (in 1920) a door was installed at the main entrance, which strongly reduced the outward airflow during the warm season. During winter the door has always been open to not restrict the inflow of cold winter air, which is the main reason for the existence of perennial ice at such a relatively low elevation.

Qualitative and a few quantitative point measurements of ice-height changes were made in the past decades but unfortunately not continuously. These observations show significant changes both in ice thickness at a given point and in the location of the interior ice limit on annual to decadal time scales. Today's inner limit of the perennial ice is the eastern border of the Eispalast (Figs. 1 and 2). This was also the case in the 1930s. In the subsequent years, however, ice started to accumulate in the depression of the U-Tunnel behind the Eispalast, in parts of the huge Midgard gallery and locally further inside the cave. Since 1945 ice has been decreasing in all interior parts of ERW and only small ice figures are left today behind the Eispalast. The Eistor, an opening at the highest point of the ice cave (see Fig. 1), did not exist in 1913. After World War I a gap opened between the rock wall and the ice (Klappacher and Knapczyk, 1985; Hauser and Oedl, 1922) and during the subsequent decades sublimation carved a wide opening exposing impressive ice stratification in the adjacent Mörk Glacier.

\subsection{Drilling site selection}

In an attempt to stay away from areas of known high ice dynamics we selected the remote Eispalast as the location of the first drilling in an East-Alpine ice cave (Figs. 1 and 2). This hall forms the innermost limit of the permanently ice-covered area and shows a rather flat, although not entirely level ice surface. The ice body actually filling the Eispalast is very likely stagnant since it is everywhere confined by cave walls (see Fig. 2) and shows no notable ice accumulation gradient, but in terms of shear stress an, in essential, horizontal ice surface. Comparisons of historical photographs (Lehmann, 1922; Klappacher and Knapczyk, 1985) and written and oral reports indicate that the height of this central ice body did not fluctuate by more than ca. $20-30 \mathrm{~cm}$ during the last ca. $60-80 \mathrm{yr}$ (at the drilling position $10-20 \mathrm{~cm}$ of ice loss seems to have occurred between 1920 and 2008), but up to ca. half a meter at its western margin (Klappacher and Knapcyzk, 1985; A. Rettenbacher, personal communication, 2010).

In addressing the liquid water sources and sinks in the Eispalast the following points are relevant: on top of the flat ice surface the generally weak inflow of water (ceasing during winter) forms a thin water film slowly extending in all directions. Excess water not freezing on may creep to the ice-free continuation of the cavern, which provides the principal liquid water sink. This behavior was observed around a dripwater source in close proximity to an ice column (see photo

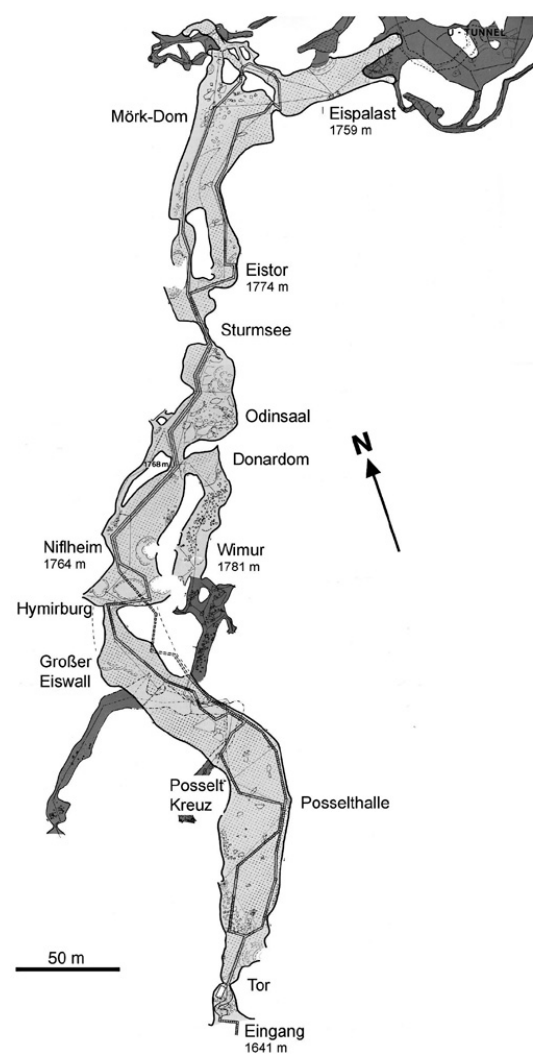

Fig. 1. Map of the ice covered part of the Eisriesenwelt cave in Austria. The ERW ice core was drilled at the innermost area called Eispalast. Light-grey areas are ice-covered, dark-gray areas are icefree.

in Fig. 2), which has only been active during the last few years. In addition to this temporally varying water source there is a more significant source above the ice cliff in the nearby Mörkdom, which is suspected to have been the main, persistent water source relevant for the ice body until being redirected away from the Eispalast by the cave management (A. Rettenbacher, personal communication, 2010). It is unknown, how this source influenced accumulation and ablation processes in the past. The air reservoir above the ice is cold and dynamic enough only during winter and spring (ice and air temperatures between $-1{ }^{\circ} \mathrm{C}$ to $-1.5^{\circ} \mathrm{C}$; wind speed about $0.2 \mathrm{~m} \mathrm{~s}^{-1}$ (max. $\left.0.6 \mathrm{~m} \mathrm{~s}^{-1}\right)$; see Obleitner and Spötl, 2010) to transfer the latent heat eventually released through the water/ice transition out of the cave. Thus potential ice accumulation is supposed to be limited to spring, while during summer freezing of water is excluded since the air temperature remains close to $0{ }^{\circ} \mathrm{C}$. Considering that the relative humidity reaches $100 \%$ in early spring (Obleitner and Spötl, 2010), freezing out of water vapor might be an additional source during this time, although most likely negligible compared to the other sources.

Regarding ice ablation, sublimation might occur during winter (see below), but should be (at least for the present 

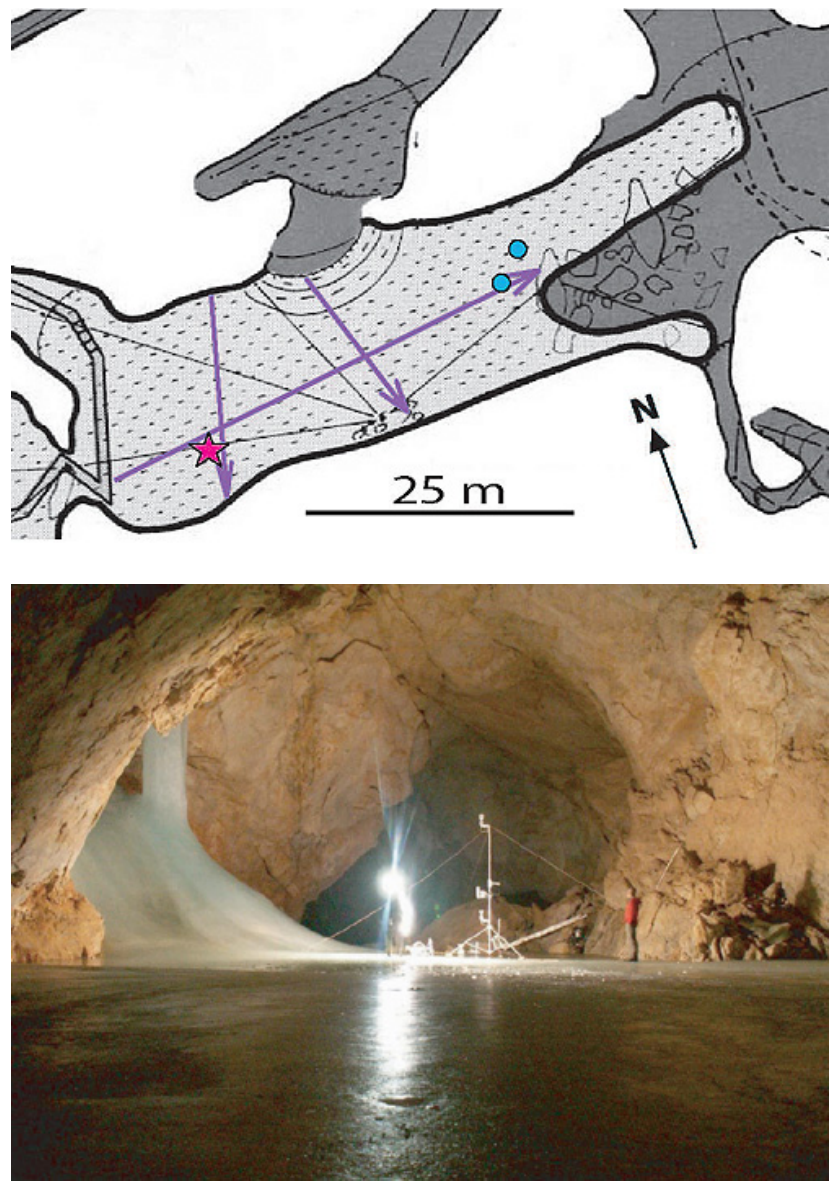

Fig. 2. Map and photo of the Eispalast. The purple arrows indicate the GPR profiles (Behm and Hausmann, 2007; Hausmann and Behm, 2010) the pink star marks the position of the core and the blue circles indicate the mass-balance measurements (stack inspection and ultrasonic ice-height recording (Obleitner and Spötl, 2010)). The photo shows the view from the tour walkway towards the eastern, ice-free part of the Eispalast and the meteorological station set up there between 2007 and 2009 next to the ice column.

time) only of minor importance because the relative humidity remains above $97 \%$ in the Eispalast (Obleitner and Spötl, 2010; sublimation, however, does play a significant role in narrow passages with high wind speeds as evidenced by large scallops on ice walls in other parts of the cave). Thus significant surface ablation in the Eispalast mainly occurs via melting during summer (and early autumn) governed by the water inflow and air temperature. We cannot strictly exclude basal melting as a contributing ablation process. On the one hand, rock temperature at $125 \mathrm{~cm}$ depth has been measured to remain below $0^{\circ} \mathrm{C}$ year round whereas the englacial temperature at $6 \mathrm{~m}$ depth of the drilling site reached $-0.2^{\circ} \mathrm{C}$ during summer (F. Obleitner, personal communication, 2010). Considering that any warming of the ice/bedrock interface above the pressure melting point is driven by a long-term increase in the cave air temperature, the mass loss at the surface
Table 1. Accumulation and ablation (negative sign) determined by ultrasonic ice-height measurements in the Eispalast over two years (values determined from data by F. Obleitner, personal communication, 2010; see also Obleitner and Spötl, 2010).

\begin{tabular}{lrr}
\hline interval & accumulation & accumulation rate \\
\hline Jun-Nov 2007 (summer/autumn) & $-3.8 \mathrm{~cm}$ & $-7.6 \mathrm{~cm} \mathrm{yr}^{-1}$ \\
Dec-Mar 2007/08 (winter) & $-0.4 \mathrm{~cm}$ & $-1.2 \mathrm{~cm} \mathrm{yr}^{-1}$ \\
Apr-Jun 2008 (spring/early summer) & $+0.04 \mathrm{~cm}$ & $+0.16 \mathrm{~cm} \mathrm{yr}^{-1}$ \\
Jul-Nov 2008 (summer/autumn) & $-2.9 \mathrm{~cm}$ & $-7.0 \mathrm{~cm} \mathrm{yr}^{-1}$ \\
Dec-Mar 2008/09 (winter) & $-0.7 \mathrm{~cm}$ & $-2.1 \mathrm{~cm} \mathrm{yr}^{-1}$ \\
Apr-Jul 2009 (spring/early summer) & $+5.2 \mathrm{~cm}$ & $+15.6 \mathrm{~cm} \mathrm{yr}^{-1}$ \\
Aug-Sep 2009 (summer/autumn) & $-0.75 \mathrm{~cm}$ & $-4.5 \mathrm{~cm} \mathrm{yr}^{-1}$ \\
\hline Jun 2007 to Oct 2009 (total) & $-3.3 \mathrm{~cm}$ & $-1.4 \mathrm{~cm} \mathrm{yr}^{-1}$
\end{tabular}

during such a warming event would be much more significant than the additional basal melting. Thus, basal melting is thought to play a very minor role at least, for the present mass balance situation. In conclusion, the poorly known liquid water sources relevant for the Eispalast are expected to comprise locally and temporally varying infiltration leading to a highly irregular variability of the net ice mass balance, both in space and time.

The net ice mass balance was recorded in the Eispalast from June 2007 to October 2009 by visual stack inspection and ultrasonic ice-height recording (for more details see Obleitner and Spötl, 2010). These measurements were carried out in the eastern part of the Eispalast close to the icefree area of the cave, next to a large ice column and about $20 \mathrm{~m}$ from the ice core drill site (see Fig. 2). Both methods consistently support the view, that (if at all) ice accumulates during spring and early summer and ablates in summer and early autumn (see Table 1). The minimal ablation occurring during winter might indicate sublimation, which is however, negligible compared to the ice loss in summer. The data by Obleitner and Spötl (2010) demonstrate that the years 2007 and 2008 are not archived in the ice as no net accumulation had occurred. How many years before 2007 are also missing due to lack of any accumulation or substantial ablation afterwards is unknown. The strong accumulation in spring 2009 might be due to the onset of drip-water discharge close to the ice column (see above). This short-term accumulation and ablation pattern, which was determined near the ice column, cannot be directly transferred to the drilling position since it is not representative of the whole Eispalast. Although ablation processes probably affect the entire Eispalast in a more uniform manner, accumulation is localized and likely varied significantly in the past (see above).

The Eispalast ice body was surveyed using Ground Penetrating Radar (GPR) profiling which suggested a maximum ice thickness of ca. $7 \mathrm{~m}$ (Behm and Hausmann, 2007; Hausmann and Behm, 2010). This value was subsequently confirmed by steam drilling. 


\subsection{Sampling and methods}

In 2007 a $7.1 \mathrm{~m}$-long ice core (denoted as ERW core) was drilled in the SW-corner of the Eispalast. Although no direct indications of bedrock (e.g. small rock fragments or silty material) were found in the bottom core sample the total core length is consistent with the GPR ice thickness estimate (Behm und Hausmann, 2007; Hausmann and Behm, 2010) confirming that the drilling reached the basal ice layer. Although equipped with a drill head specifically designed by the Physical Institute of the University Bern for ice near the melting point (the same equipment was already used successfully in the Dobsina ice cave, Slovakia - Vrana et al., 2007) drilling proved extremely difficult (also due to insufficient electric power supply) and required the use of ethanol as drilling fluid. As a result, the overall quality of the 3-inch core is poor, as it is broken up into more than 100 individual pieces of 1 to $60 \mathrm{~cm}$ in length.

Following on-site core logging, a detailed visual stratigraphy based mainly on the geometry and qualitative number density of air bubbles and the succession of impurity layers was established in the cold laboratory at the Institut für Umweltphysik, Universität Heidelberg. Where feasible we sub-sampled at an average depth resolution of $2 \mathrm{~cm}$. From these samples quasi-continuous depth profiles were obtained for gravimetric ice density, electrolytic conductivity, and stable water isotopes $\left(\delta \mathrm{D}\right.$ and $\delta^{18} \mathrm{O}$ ). The ice density profile (not shown) reveals no significant changes or a notable trend (average value: $0.87 \pm 0.18 \mathrm{~g} \mathrm{~cm}^{-3}$ ).

Isotope mass spectrometric analyses (performed at the Institut für Geologie und Paläontologie, Universität Innsbruck) comprised $\delta^{18} \mathrm{O}$ measurements using a Delta ${ }^{\text {plus }} \mathrm{XL}$ mass spectrometer after equilibration with carbon dioxide and $\delta \mathrm{D}$ determination using a Delta Advantage mass spectrometer following reduction to $\mathrm{CO}$ and $\mathrm{H}_{2}$ in a TC/EA pyrolysis unit. Standardization was accomplished using in-house water standards calibrated against VSMOW, GISP and SLAP. While these standard procedures yield a long-term precision of $0.08 \%$ and $1.0 \%$ for $\delta^{18} \mathrm{O}$ and $\delta \mathrm{D}$, respectively, a potential source of uncertainty is the contamination of the samples with ethanol used for drilling. Investigations of this effect showed that a $1 \%$ ethanol contribution would shift the $\delta \mathrm{D}$ value by $0.5 \%$ and the $\delta^{18} \mathrm{O}$ value by $0.04 \%$. Assuming a maximum ethanol contribution of typically less than $5 \%$ the shift in $\delta \mathrm{D}$ and $\delta^{18} \mathrm{O}$ would be less than $2.5 \%$ and $0.2 \%$, respectively. This translates into D-excess values being systematically higher by up to $0.5 \%$.

Discrete sub-sampling of the core comprised 70 aliquots à $5 \mathrm{~cm}$ long that were filtered for gravimetric determination of insoluble particle mass concentrations. A subset of seven samples of this insoluble material was used for the quantification of the inorganic and organic carbon content following the methods described by May (2009). In brief, quantification of the inorganic carbon fraction comprised extraction of $\mathrm{CO}_{2}$ via $20 \%$ phosphoric acid treatment followed by

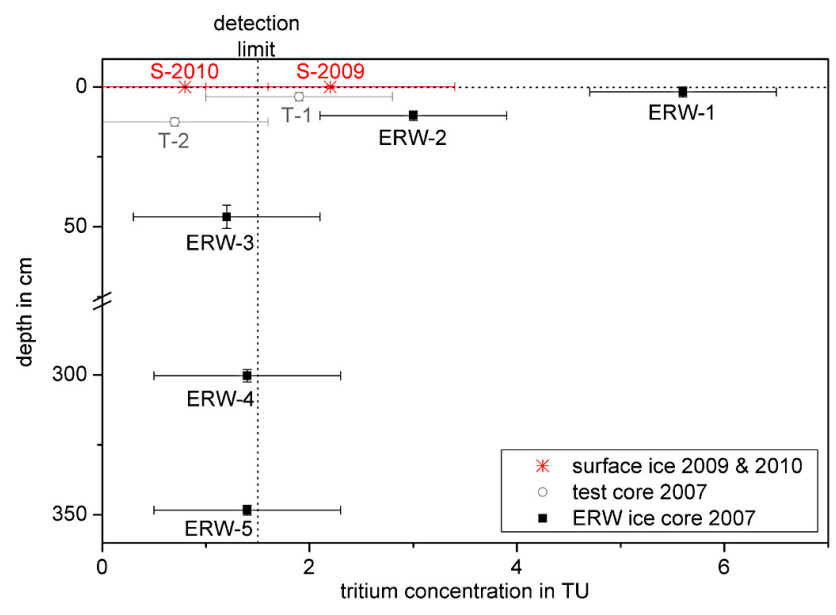

Fig. 3. Tritium concentration in five samples from the ERW ice core (black), two samples from the parallel-drilled test core (gray), and two surface samples taken in 2009 and 2010 (red). Note the break in the y-axis from 75 to $275 \mathrm{~cm}$.

bubble degassing, cryo-cleaning and cryo-trapping. The remaining acidic solution was filtered again through a quartz filter, which was combusted in a sealed quartz glass tube. For both fractions the carbon mass was determined manometrically with an analytical uncertainty of $0.8 \mu \mathrm{C}$ providing a detection limit of $2.5 \mu \mathrm{g} \mathrm{C}$.

Seven of the particulate organic carbon samples were analyzed for radiocarbon $\left({ }^{14} \mathrm{C}\right)$ by accelerator mass spectrometry (AMS) at the VERA Laboratory, Universität Wien (Steier et al., 2006; Liebl et al., 2010).

Additional analyses of insoluble inorganic matter comprising scanning electron microscopy (SEM) and stable isotopic composition were performed at the Institut für Geologie und Paläontologie, Universität Innsbruck, using standard techniques described in Spötl and Vennemann (2003). Data are reported on the VPDB scale and precision is better than $0.1 \%$ o for $\delta^{13} \mathrm{C}$ and $\delta^{18} \mathrm{O}$.

Eight filtered samples were also examined for their pollen contents by S. Bortenschlager (Institut für Botanik, Universität Innsbruck).

Finally, for gaining insight into the recent accumulation history, tritium $\left({ }^{3} \mathrm{H}\right.$, half-life $\left.12.3 \mathrm{yr}\right)$ was measured at five levels from the surface down to $350 \mathrm{~cm}$. The 2.5 to $4 \mathrm{~cm}-$ thick core samples are supplemented by two samples from the parallel-drilled test core. Additionally, two surface ice samples were taken (i) in March 2009 in advance to the significant ice accumulation observed near the ice column by ultrasonic ice-height measurements (see Table 1), and (ii) in June 2010 (in addition to samples from the drip water source near the ice column and an ice stalagmite beneath this dripping point). Tritium analyses were performed at the Institut für Umweltphysik by low-level gas counting providing a detection limit typically around $1.5 \mathrm{TU}$ (tritium units). 
Table 2. $\mathrm{F}^{14} \mathrm{C}$ and $\delta^{13} \mathrm{C}$ data of particulate organic carbon (POC) determined in ERW ice core samples. All samples have a length of about $5 \mathrm{~cm}$ (except V50189 with $10 \mathrm{~cm}$ ). Along with the analyzed POC mass, isotope ratios are reported as $\delta^{13} \mathrm{C}$ and $\mathrm{F}^{14} \mathrm{C}$ (fraction modern carbon; Reimer et al., 2004), respectively. The background corrected ${ }^{14} \mathrm{C}$ data, $\mathrm{F}^{14} \mathrm{C}_{\text {corr }}$, assume a uniform background contribution estimated by the average of the samples V50188, V50393 and V50191 (note that the given uncertainties refer to analytical errors only). The calibrated radiocarbon age (calculated with $\mathrm{O} \times \mathrm{Cal} 4.1$ ) refers to the $2 \sigma$ - probability range.

\begin{tabular}{lccccccc}
\hline $\begin{array}{l}\text { VERA } \\
\text { No. }\end{array}$ & $\begin{array}{c}\text { mean depth } \\
{[\mathrm{cm}]}\end{array}$ & $\begin{array}{c}\text { ice mass } \\
{[\mathrm{g}]}\end{array}$ & $\begin{array}{c}\mathrm{POC} \\
{[\mu \mathrm{gC}]}\end{array}$ & $\begin{array}{c}\delta^{13} \mathrm{C} \\
{[\%]}\end{array}$ & $\mathrm{F}^{14} \mathrm{C}$ & $\mathrm{F}^{14} \mathrm{C}_{\text {corr }}$ & $\begin{array}{c}\text { cal. age }(2 \sigma) \\
{[\mathrm{BP}]}\end{array}$ \\
\hline V50188 & $210 \pm 3$ & 25 & $14.7 \pm 0.8$ & -28 & $0.757 \pm 0.008$ & background & - \\
V50393 & $341 \pm 3$ & 28 & $15.0 \pm 0.8$ & -32 & $0.771 \pm 0.010$ & background & - \\
V50394 & $396 \pm 3$ & 20 & $27.4 \pm 0.8$ & -30 & $0.738 \pm 0.008$ & $0.711 \pm 0.018$ & $2355-3355$ \\
V50189 & $573 \pm 5$ & 54 & $59.8 \pm 0.9$ & -27 & $0.655 \pm 0.009$ & $0.621 \pm 0.013$ & $3825-4810$ \\
V50392 & $628 \pm 3$ & 20 & $24.3 \pm 0.8$ & -34 & $0.702 \pm 0.010$ & $0.619 \pm 0.028$ & $3400-5300$ \\
V50190 & $668 \pm 3$ & 23 & $122.0 \pm 1.2$ & -30 & $1.123 \pm 0.009$ & - & - \\
V50191 & $710 \pm 3$ & 26 & $12.2 \pm 0.8$ & -22 & $0.763 \pm 0.010$ & background & - \\
\hline
\end{tabular}

\section{Results and discussion}

\subsection{Age structure}

As displayed in Fig. 3 only samples of the upper $10 \mathrm{~cm}$ exceed the quantitative tritium detection limit of $1.5 \mathrm{TU}$. Moreover, the maximum value of $5.6 \pm 0.9 \mathrm{TU}$ at the core top is close to or even below the (almost natural) tritium level in modern precipitation of around $10 \mathrm{TU}$ indicating that the bomb tritium peak of 1963 due to thermo-nuclear tests is not present in the ice body. Missing of this dominant atmospheric signal requires a total loss or lacking of any net accumulation after the late 1950s. Noting the net lowering of the surface-ice level by $10-20 \mathrm{~cm}$ observed between 1920 and 2008, corresponding to an overall net ablation rate of 0.1 to $0.2 \mathrm{~cm} \mathrm{yr}^{-1}$ in the last century, such a loss seems realistic. We then expect the upper tritium values to contain either bomb tritium from the pre-1963 period or relative recent ice deposits carrying the modern tritium level ranging from 5-15 TU (Austrian Network of Isotopes in Precipitation (ANIP), 2010), while the potentially deposited bomb tritium has been entirely removed already.

The tritium value of $2.2 \pm 0.9 \mathrm{TU}$ from the 2009 ice surface sample is clearly below the value from the 2007 surface recovered from the ice core top and the 2010 sampled surfaceice contains no tritium at all. This finding suggests that ice has also partly accumulated from melt water tagged by a subnatural tritium level (e.g. through melting of older ice in the adjoining Mörkdom and melt water runoff into the Eispalast) or that the ablation as observed by Obleitner and Spötl (2010) has brought the sub-surface tritium values to the present top of the ice body. Future monitoring of the evolvement of the tritium content in the surface ice would allow determining if and for how long the actual negative mass balance period persists.

Aimed at constraining the age of the cave ice ${ }^{14} \mathrm{C}$ analysis on the particulate organic carbon fraction was attempted on seven samples (see Table 2). Investigations of the particulate matter showed that at total mass concentrations between $1 \mu \mathrm{g} \mathrm{ml}^{-1}$ and $1 \mathrm{mg} \mathrm{ml}^{-1}$ (median: $56 \mu \mathrm{g} \mathrm{ml}^{-1}$ ) 30 to $90 \%$ of the filterable matter is inorganic carbon. In addition, some traces of organic carbon $(0-4 \%)$, but only few pollen were found. Thus the particulate organic carbon concentrations of the analyzed sub-samples are in the order of 0.5 to $1 \mu \mathrm{gC} \mathrm{ml}{ }^{-1}$. However, any background contributions are unknown, thus the data reflect rather an upper limit than a typical value. While these values suggest the presence of sufficient organic matter for radiocarbon dating in the future, the extracted organic carbon masses are only between 12 and $60 \mu g C$ providing a challenge for the ${ }^{14} \mathrm{C}$ dating technique. Moreover, the possible disturbance of the ${ }^{14} \mathrm{C}$ value due to the large inorganic carbon fraction (hard-water effect) as well as the unknown origin of the organic carbon fraction (e.g. soil reservoir effect) provides serious problems for the use of ${ }^{14} \mathrm{C}$ as a dating tool.

Indeed, ${ }^{14} \mathrm{C}$ values (reported as fraction modern carbon $\mathrm{F}^{14} \mathrm{C}$ as defined by Reimer et al., 2004) range between 0.65 and 0.77 without a systematic change with depth excluding the second deepest sample, whose value of 1.12 exceeds the present-day atmospheric level. Reasons for this inconclusive findings might be the disturbance of the ${ }^{14} \mathrm{C}$ signal by the large amount of inorganic carbon (although the $\delta^{13} \mathrm{C}$ signal does not indicate a significant influence), a contribution from ethanol, which might have contaminated the particles, and the overall small organic carbon masses, making the ${ }^{14} \mathrm{C}$ analysis very sensitive to the methodical background (which was not determined beforehand)

However, in order to get at least an idea about the order of magnitude covered by the ice to compare with other ice caves, we developed a crude scenario. Assuming the

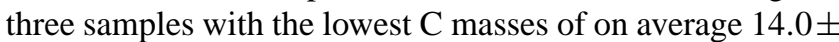
$0.5 \mu \mathrm{gC}$ and a similar ${ }^{14} \mathrm{C}$ signature of $0.764 \pm 0.009 \mathrm{might}$ reflect the process background (note that the errors give the 
mean measurement uncertainty, not the deviation of the values) and neglecting the over-recent value, leaves three, potentially useful ${ }^{14} \mathrm{C}$ values between 400 and $630 \mathrm{~cm}$ depth. The formal uncertainty of the corrected $\mathrm{F}^{14} \mathrm{C}$ values shown in Table 2 reflect a purely analytical uncertainty, accounting for the measurement uncertainties of the carbon mass and the ${ }^{14} \mathrm{C} /{ }^{12} \mathrm{C}$ ratio for both the background as well as the sample values. The resulting span of the ${ }^{14} \mathrm{C}$ age presents therefore a lower limit and is very likely significantly larger. The three background-corrected values translate into calibrated ${ }^{14} \mathrm{C}$-ages between 2355 and $5300 \mathrm{yr} \mathrm{BP}$, increasing with depth, and suggest an overall mean annual layer thickness of $0.14 \mathrm{~cm}$, which, if extrapolated to the cave bottom, provides a hypothetical basal ice age of around $5000 \mathrm{yr}$. Clearly, further dating attempts are needed to substantiate this age estimate, including a careful determination of background contributions. Even more important, possible reservoir effects as well as disturbances by inorganic carbon have to be investigated.

Overall, we could not gain conclusive information about the accumulation history and the associated age structure of the ice body in the Eispalast. Nevertheless, there is clear evidence for a recent net ablation period, which removed all ice potentially accumulated, at least, since the mid-1950s. This caveat actually hampers the following discussion of the significant changes seen in the ice-core stratigraphy of soluble and insoluble impurities as well as in the stable water isotopes $\left(\delta \mathrm{D}\right.$ and $\left.\delta^{18} \mathrm{O}\right)$.

In contrast to ERW, two shallow ice cores drilled in the static Bortig cave (1236 m a.s.l., Bihor Mountains, Romania) in 2005 still showed high-resolution changes of bomb tritium, indicating no substantial ice loss (Kern et al., 2009). Similarly, the ${ }^{14} \mathrm{C}$ ages derived at other ice caves are significantly younger (for references see Introduction) compared to our estimate for ERW. However, theses caves are mostly static ones, thus differing significantly from ERW in terms of their cave meteorology and, most important, in their controlling accumulation/ablation processes.

\subsection{Visual stratigraphy, insoluble impurities and electrolytic conductivity profiles}

Inspecting the visual stratigraphical features we identified three core sections: the upper core at $\sim 0-200 \mathrm{~cm}$, the middle part between $\sim 200-400 \mathrm{~cm}$, and the lower section at $\sim 400$ $710 \mathrm{~cm}$. The upper and middle core sections are characterized by large $(\sim 5 \mathrm{~mm})$, vertically elongated air bubbles and by the occurrence of clearly visible impurity layers particularly in the mid-core section. In contrast, small $(<2 \mathrm{~mm})$, round air bubbles and rather evenly distributed patches of ochre-colored particles as well as a few distinct particle layers are seen in the lower core section. The differences in the bubble and impurity stratigraphy might indicate changes in the main ice-forming processes. Bubble nucleation in freezing water at equilibrium with the atmosphere has been inves-

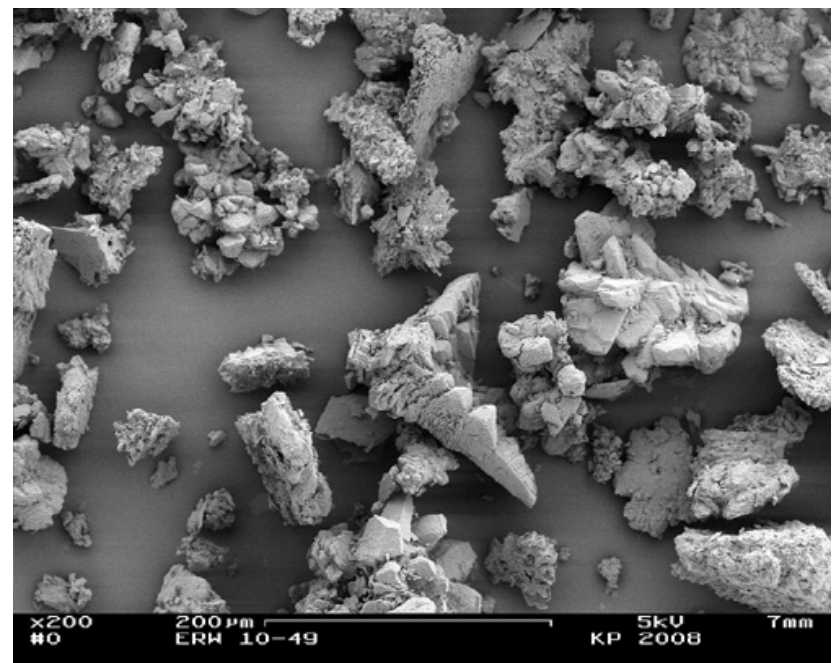

Fig. 4. SEM image of calcitic residue retrieved from the ice core drilled in the Eispalast at a depth of $260 \mathrm{~cm}$ consisting of diverse crystal aggregates and fragments thereof.

tigated by Carte (1961) and later by Hubbard (1991). Following these authors air components initially dissolved in the liquid water are rejected from the developing ice front until the air concentration in the water layer reaches (super-)saturation leading to bubble formation. More abundant and thus smaller bubbles occur preferentially at high freezing rates, while below $1 \mathrm{~mm} \mathrm{~min}{ }^{-1}$ cylindrical threads of air are formed parallel to the direction of ice crystal growth. There are other factors than the freezing rate, which influence bubble formation including water-layer thickness, particulate matter content and the amount of dissolved gases. Especially the two latter points might link bubble formation to calcite precipitation.

Visual inspection of the melted $2 \mathrm{~cm}$-aliquots shows white flakes and crystals dominating the upper and mid-core part, whereby the lower core contains mainly ochre silt. These findings are in agreement with the ice stratigraphy. As already discussed above, $30-90 \%$ of the particle mass is made up by inorganic carbon. Macroscopically, this material is fine-grained "dust" ranging in color from white to lightbrown. Under the SEM aggregates of crystals are seen which vary in size from a few tens up to ca. $200 \mu \mathrm{m}$. These crystals - low-Mg calcite according to X-ray diffraction analysis - are mostly euhedral (rhombohedral) attesting to their nondetrital origin (Fig. 4). A small and variable percentage of grains, however, appears somewhat rounded and lacks crystal terminations. These grains are interpreted as detrital, probably being derived from weathering of the limestone walls and ceilings.

The stable isotopic composition of 50-300 $\mu \mathrm{g}$ bulk samples shows very high $\delta^{13} \mathrm{C}$ values which plot within the field characteristic of cryogenic calcite formed by rather rapid freezing of a thin water film (Fig. 5). Many ice caves show 


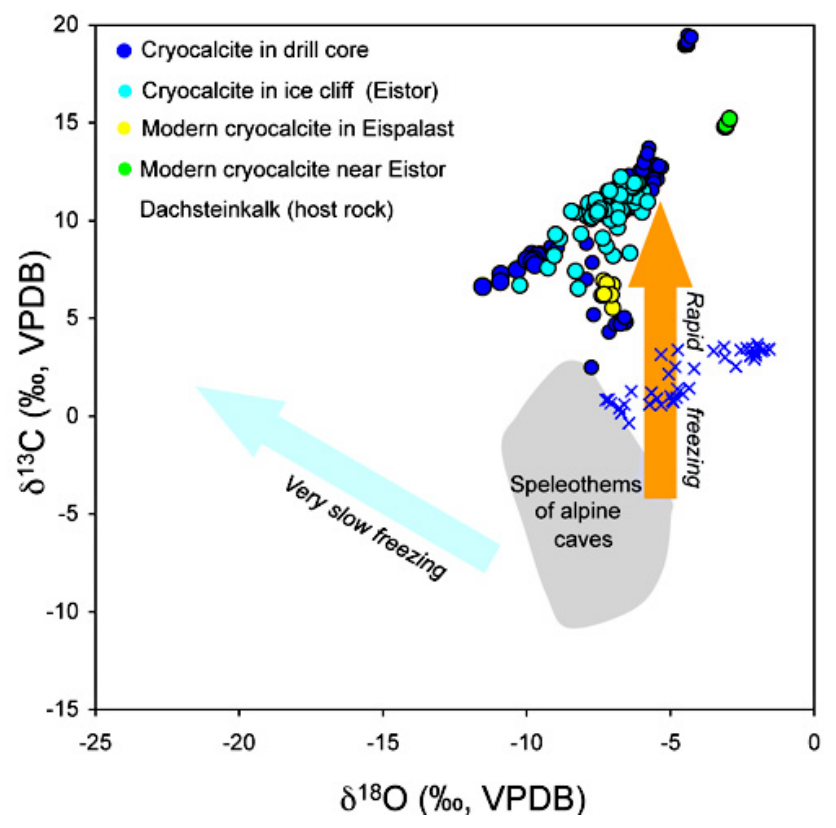

Fig. 5. Stable istopic composition of calcite extracted from "dust layers" in the drilled ice core in comparison to samples previously analyzed from similar layers in the well-stratified ice at the nearby Eistor (Spötl, 2008) and modern samples of cryogenic calcite silt collected on the ice surface in spring of 2008. The arrows indicate two evolutionary pathways observed in studies of cryogenic calcite precipitates. Note the high $\mathrm{C}$ isotope values of Eisriesenwelt cryocalcite as compared to (a) values of typical dripstones (stalagmites, flowstones) from caves in the Alps and (b) samples of the host rock in which Eisriesenwelt developed.

thin deposits of inorganically precipitated calcite resulting from the super-saturation of freezing water (e.g. Žák et al., 2008) and a previous study identified cryocalcite layers as the origin of distinct "dust layer" in the ice cliff at the Eistor (Spötl, 2008). Their isotopic composition overlaps with that observed in samples from the drilled ice core in the Eispalast (Fig. 5). Some samples show a deviation toward lower $\delta^{13} \mathrm{C}$ values partly approaching the composition of the Dachsteinkalk (Fig. 5). These samples are interpreted as being mixtures of cryocalcite and fine detrital debris derived from weathering of the host rock under these cold conditions (see above).

Observations made in Eisriesenwelt during late winter of 2008 revealed that sublimation in certain parts of the cave results in a thin layer of white cryocalcite "dust" on the dry ice surface, i.e. the ice contains disseminated cryocalcite particles which become concentrated and form a residue when the ice is removed by sublimation. Their stable isotopic composition is comparable to that of the older cryocalcite sampled in deeper ice layers below $500 \mathrm{~cm}$ (Fig. 5). In areas of sufficiently strong draft (narrow passages) these crystals can be transported over short distances forming mm-thin deposits. The cliff at the Eistor demonstrates that these "dust" layers pinch out laterally and may reach up to $\mathrm{ca} .1 \mathrm{~cm}$ in thickness (more typically less than $3 \mathrm{~mm}$ ). There, the thinner "dust layer" are typically white; the thicker ones tend to show a gradation toward ochre and light-brown. We speculate that the latter deposits accumulated over several seasonal cycles (and represent "aging" of the silt-size crystals due to diagenetic processes affecting them during the warm season when liquid water is available). The drilling in the Eispalast penetrated a series of "dust layers", but it might be possible that there have been even more (and thicker ones) which represented weaknesses of the core and are not recorded because of core breaks.

In essence, the presence of cryocalcite ("dust") layers indicate intervals of significant loss of ice in the Eispalast during winter sublimation (or maybe even during summer melting, if the calcite particles are not completely removed by water run-off). The thicker the layers the more ice had to be removed (vertically and/or laterally). Admittedly, the formation of such horizons in the Eispalast and associated implications on the net ice accumulation rate still deserve detailed investigations. This phenomenon may differ largely from place to place in the cave system leaving, among others, the question on the governing mechanism leading to exceptionally thick layers (e.g. the role of sublimation versus melt-water cycling).

The simple stratigraphical differentiation of the core suggested by the visual stratigraphy and the insoluble particle content is mirrored by the quasi-continuous resolution of the electrolytic conductivity (Fig. 6) and the stable isotope record (Fig. 7). Mean conductivity level (related to the total ion content and composition) is around $21 \pm 16 \mu \mathrm{S} \mathrm{cm}^{-1}$ in the upper section, nearly doubles in the middle part and drops again in the lower part down to $17 \pm 9 \mu \mathrm{S} \mathrm{cm}^{-1}$. In the upper and middle core sections the conductivity peaks perfectly match the visually identified presence of white calcite crystals and show a high variability. In the lower core section, where the conductivity signal is smoother and where the insoluble particles are associated with ochre-brown silt, no such co-variance is found.

Similarly, the isotope $\left(\delta \mathrm{D}\right.$ and $\left.\delta^{18} \mathrm{O}\right)$ values exhibit the largest variability in the upper core section. While the mean level is slightly lower there than in the lower part, it significantly drops in the mid core section. In contrast to the conductivity profile there is no obvious co-variance between the isotope signal and the visual identification of insoluble particles.

Overall the core contains very distinct features both in the visual stratigraphy as well as the proxy records. With an overall mean of $24 \mu \mathrm{S} \mathrm{cm}^{-1}$ and a range of 2 to $124 \mu \mathrm{S} \mathrm{cm}^{-1}$ (median: $19 \mu \mathrm{S} \mathrm{cm}^{-1}$ ) the electrolytic conductivity is surprisingly low. This range is much lower compared to the variability of the ion concentration observed in the Dobsina cave ice, which spans up to six orders of magnitude (Clausen et al., 2007). The mean level is roughly an order of magnitude less compared to karst spring water of e.g. the nearby Dachstein 


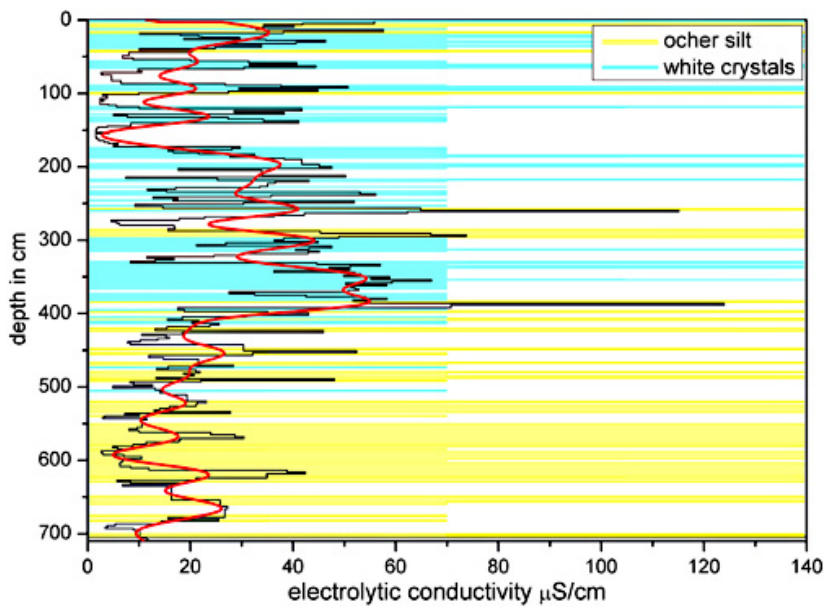

Fig. 6. Electrolytic conductivity of the quasi-continuous $2 \mathrm{~cm}$ aliquots (black line) together with the stratigraphy of particles qualitatively observed in the melted aliquots. The conductivity data was transferred onto an equidistant record with a resolution of $0.1 \mathrm{~cm}$, where gaps were linearly interpolated before a $25 \mathrm{~cm}$-running average of the equidistant data was created (red line).

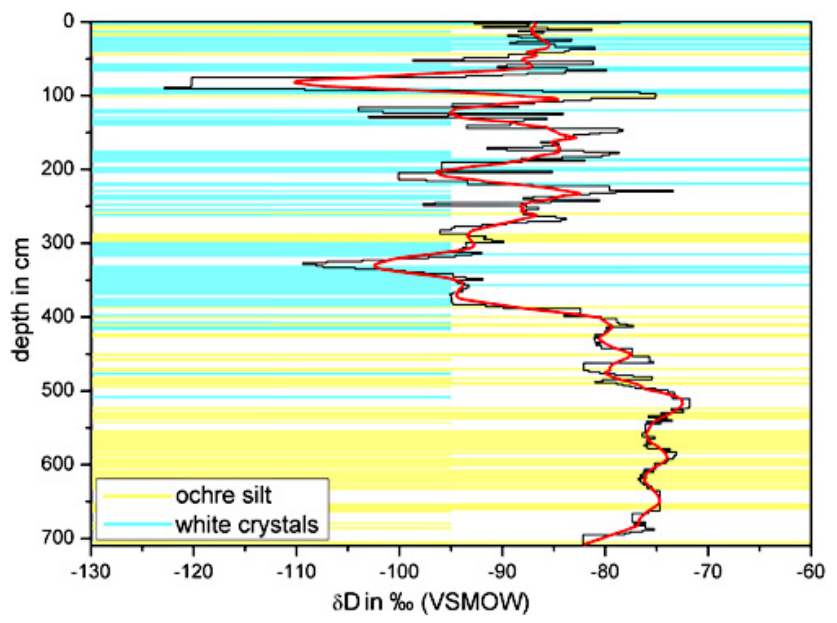

Fig. 7. $\delta \mathrm{D}$ record of the quasi-continuous $2 \mathrm{~cm}$-aliquots superimposed on the stratigraphy based on the qualitative identification of particles observed in the melted aliquots. The data was transferred onto an equidistant record with a resolution of $0.1 \mathrm{~cm}$, where gaps were linearly interpolated before a $25 \mathrm{~cm}$-running average of the equidistant data was created (red line).

massif (Scheidleder et al., 2001), whereas the minimum values approach the conductivity level typically observed in precipitation or the seasonal snow cover of high Alpine areas. Since the ice is mainly formed from drip water which is expected to provide an electrolytic conductivity value in the order of some $100 \mu \mathrm{S} \mathrm{cm}^{-1}\left(150 \mu \mathrm{S} \mathrm{cm}^{-1}\right.$ were observed in May 2010 in the Eispalast) we expect that strong salt exclusion prevails upon freezing. This implies a relatively low freezing rate (and/or a series of several melt-freeze cycles) both favoring a high degree of salt exclusion (Killawee et al., 1998). This also suggests that the conductivity variability (being particularly distinct in the upper core section) might be mainly associated with the freeze-on process of the surface water rather than with changes of the ion content in the drip-water source.

\subsection{Variability of stable water isotopes}

In discussing the water isotope profiles we presume ice formation being governed by seasonal freezing of a mostly stagnant water film to the flat Eispalast floor and that this open system is mainly fed by various drip-water sources. The accumulated ice layers may be subsequently removed in parts by melting and excess water runoff or, at lesser extent by sublimation. While ice ablation either by melting or sublimation operates without isotope fraction (disregarding the liquid like water films at grain boundaries), freezing always leads to an enrichment of the heavy isotope species in the ice relative to the (parent) water (Gat, 1996). At isotope equilibrium this fractionation increases the $\delta^{18} \mathrm{O}$ and $\delta \mathrm{D}$ values of ice by around $2.9 \%$ and $21 \%$, respectively (Lehmann and Siegenthaler, 1991), while, depending on the freezing and water mixing rates, somewhat lower values may hold under natural (i.e. non-equilibrium) conditions (Souchez and De Groote, 1985; Jouzel and Souchez, 1982). The time represented by the typical $2 \mathrm{~cm}$-intervals of our isotope samples is essentially unknown and might vary significantly (from a single to several freeze-on events separated by extensive hiatuses). However, in a rather simplistic view we may assume that this characteristic time will not systematically increase with depth, which implies that the entire ice body of the Eispalast is not deforming (i.e. zero vertical strain everywhere). This view is corroborated by the distinct peaks in the conductivity signal showing a quite comparable width within the top and bottom core sections, respectively (see Fig. 6)

Attempting to place the variability of the ERW isotope values within the context of the principle water source, we compared in Table 3 the ice-core data with geographically related precipitation and karst spring water data. We selected the 29-yr long (1980-2009) precipitation record of the Patscherkofel site available from the ANIP database (Austrian Network for Isotopes in Precipitation, 2010). Belonging to the northern Alpine rim $135 \mathrm{~km}$ west of ERW, its altitude of $2245 \mathrm{~m}$ a.s.l. is comparable to that of the Tennengebirge plateau, ensuring at both sites broadly similar isotopic properties of the precipitation particularly regarding a relative insignificant sub-cloud evaporation effect (Fröhlich et al., 2008). The spring data were compiled from a multi-year study performed at the Dachstein karst massif situated ca. $35 \mathrm{~km}$ east of ERW (Scheidleder et al., 2001). From this data base we selected 12 springs characterized by a catchment area around $2000 \mathrm{~m}$ a.s.l. and by no direct glacier meltwater influence. This comparison reveals that the overall mean $\delta^{18} \mathrm{O}$ value in the ERW core is slightly higher than the 
Table 3. Statistical data of $\delta^{18} \mathrm{O}$ and Deuterium excess d, including mean values, standard deviation, max./min. range and seasonal range, as well as slope s and its seasonal range in the ERW ice core, at the Patscherkofel site and 12 springs in the Dachstein area.

\begin{tabular}{|c|c|c|c|c|c|c|c|c|c|c|c|}
\hline & & \multicolumn{4}{|c|}{$\delta^{18} \mathrm{O}[\% o]$} & \multicolumn{4}{|c|}{ Deuterium excess d [\%o] } & \multicolumn{2}{|r|}{ slope } \\
\hline & & mean & SD & range & seasonal & mean & SD & range & seasonal & $\mathrm{s}$ & seasonal \\
\hline \multirow{3}{*}{ ERW core $^{1}$} & $0-7.1 \mathrm{~m}$ & -11.6 & 1.3 & -17.1 to -9.8 & - & 7.9 & 1.6 & 3.9 to 14.6 & - & 7.25 & - \\
\hline & $0-4 \mathrm{~m}$ & -12.3 & 1.2 & -17.1 to -10.2 & - & 8.2 & 1.8 & 3.9 to 14.6 & - & 6.9 & - \\
\hline & $4-7.1 \mathrm{~m}$ & -10.5 & 0.3 & -11.6 to -9.8 & - & 7.4 & 1 & 4.9 to 10.5 & - & 7.1 & - \\
\hline \multicolumn{2}{|c|}{ Patscherkofel ${ }^{2}$} & -14.3 & 3.7 & -22.8 to -4.6 & -18 to -10 & 11.2 & 3.1 & 1.1 to 18.8 & 8 to 14 & 8.3 & 7.99 to 8.35 \\
\hline \multicolumn{2}{|c|}{ Dachstein springs 3} & -12.7 & 0.1 & -13 to -12.5 & -17 to $-7^{4}$ & 10.8 & 0.4 & 9.9 to 11.4 & negligible & 7.9 & - \\
\hline
\end{tabular}

1 based on $2 \mathrm{~cm}$-samples

2 based on monthly mean data (ANIP, 2010)

3 based on inter-site variance (Scheidleder et al., 2001)

${ }^{4}$ based on the seasonal variance only seen in 5 from a total of 53 Dachstein springs investigated

respective precipitation and spring water means. Although this finding suggests to reflect the isotope fractionation effect during cave ice formation from liquid water, these systematic differences are inconclusive in view of the potential long-term temporal change of the mean isotope values. Nevertheless, we note that the mean $\delta^{18} \mathrm{O}$ value of the ice core is higher than the spring water value by $0.4 \% o$ in the upper $4 \mathrm{~m}$ and by $2.2 \%$ in the bottom $3 \mathrm{~m}$ of the core, which is difficult to explain in terms of a climatic isotope temperature effect.

However, looking at the co-isotope-properties provided by the Deuterium excess d (defined as $\mathrm{d}=\delta \mathrm{D}-8 \delta^{18} \mathrm{O}$, i.e. reflecting the deviation from the global meteoric water line) and the slope $\mathrm{s}$ of the $\delta \mathrm{D}$ versus $\delta^{18} \mathrm{O}$ regression line, provides more insights. The $\mathrm{d}$ and s parameters are significantly lower in the ERW core compared to the respective precipitation and spring water values, which, most likely, is due to the isotope fractionation during ice formation. Following Souchez and Jouzel (1982) consecutive samples should plot on the so-called freezing line with a slope smaller than 8 depending on the initial isotope values of the parent liquid water. As a consequence of this reduced slope the $d$ value would then be smaller as well. Taking the mean of the spring water $\left(-12.7 \%\right.$ ) as the initial $\delta^{18} \mathrm{O}$ value and deploying the equilibrium fractionation factors of Lehmann and Siegenthaler (1991), we derive a freezing slope of 6.7. Since consecutively formed ice layers are unlikely to be resolved in our data and the parent water may change for various reasons this expected slope is still lower than the observed 7.25 (6.9 in the upper and 7.1 in the lower section - see Fig. 8). Nevertheless, inspection of steady changes in the ERW isotope profile over a couple of $10 \mathrm{~cm}$-intervals yields slope values between 7.0 and 6.3 (mean 6.6), hence close to the freezing line slope. Indeed, we measured in June 2010 a $\delta^{18} \mathrm{O}$ value in the dripping water of $-12.3 \%$. This value is virtually identical to the spring water mean but lower by $2.3 \%$ o than the near surface value of a small ice (stalagmite) formed below the dripping point.

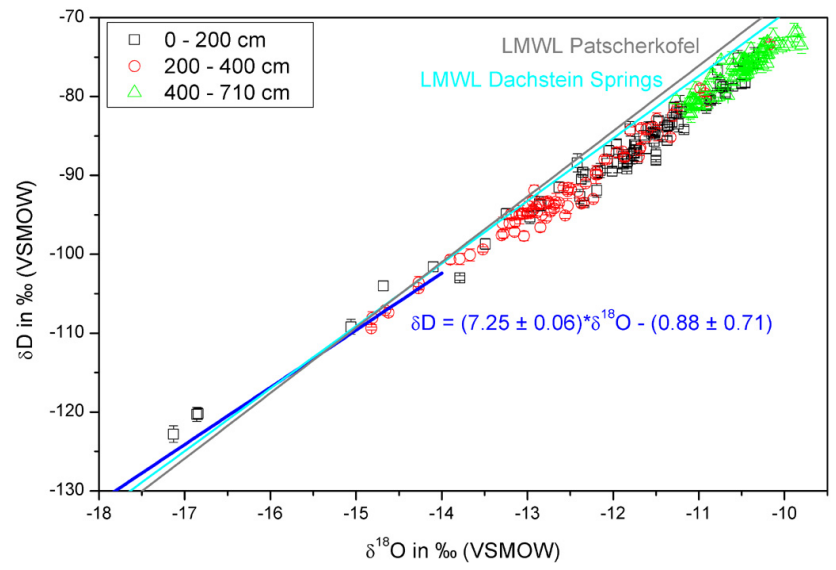

Fig. 8. $\delta \mathrm{D}$ versus $\delta^{18} \mathrm{O}$ : the color coding denotes the three core sections discussed above. The dark blue line gives the linear regression of the complete isotopic data set. The light blue and gray lines show the local meteoric water line (LMWL) derived from the data set of 12 springs in the Dachstein area (Scheidleder et al., 2001) and from the Patscherkofel site (ANIP, 2010), respectively.

It remains difficult, however, to conceive the relatively large range of the individual isotope values in the icecore profile, which is comparable to the typical summerto-winter contrast seen in monthly precipitation samples at Patscherkofel. Regarding the seasonality of the isotope signal in the dripping water source (not measured) we expect a considerable smoothing by the snow pack, the water flow through the 400-500 m-thick karstified limestone, and the limited depth resolution of $2 \mathrm{~cm}$. In any case, a notable seasonal cycle would be phase-shifted towards the end of the year. Indeed, within the 53 Dachstein springs studied by Scheidleder et al. (2001) only five showed a distinct seasonal $\delta^{18} \mathrm{O}$ signal (maximum range -17 to $-7 \%$ o) while in the remaining ones the seasonal amplitude was very subdued (around $1.5 \%$ at most) or almost absent (less than $0.5 \% o$ ). Thus, judging whether the rather strong high 
frequency variability of the ERW core data might be driven by isotope changes of the drip-water or by varying processes in the formation of the individual ice layers requires monitoring of the isotope seasonality in the drip water. Whatsoever, the reason for the marked drop from more depleted and strongly varying values in upper core section to higher and smoother ones in lower sections remains elusive. In any case, this systematic change is likely associated with the ice-formation process (depending on the cave climate) rather than the result of a direct climate effect carried by the isotope properties of the water source itself.

\section{Conclusions and outlook}

Ice core drilling performed down to bedrock of the approximately $7 \mathrm{~m}$-thick ice body which fills the floor of the Eispalast cavern in the ERW karst system proved difficult in view of obtaining non-fractured core samples. First attempts aimed at deriving quantitative information on the recent accumulation history as well as on an age constraint by radiometric dating remained inconclusive, since (i) recent ablation led to an almost complete loss of bomb-derived tritium leaving the actual ice surface at tritium levels significantly below the natural level and (ii) the extremely low particulate organic content of the particulate matter and the small carbon masses extracted prevented a useful quantification of the radiocarbon results in terms of ice age. Nevertheless a very rough estimate of the radiometric age points to an age of several thousand years, which implicates a relatively well-balanced equilibrium between ice ablation and accumulation persisting on the millennial scale. Provided that the ice body is indeed old enough and, hence, suitable for radiocarbon dating, a new and uncontaminated ice core (providing compact samples as preferentially obtained by a large diameter thermal drill) would be needed for ${ }^{14} \mathrm{C}$ dating. In this case also the dissolved carbon fraction may be envisaged for that purpose (May, 2009). If successful, dates of substantial massbalance changes as well as the date of first formation of the ice body would be the prime climate signals obtained from the ice cave.

The ice-core stratigraphy was found to be characterized by a clear dichotomy between the top $2 \mathrm{~m}$ and bottom $3 \mathrm{~m}$ of the profile (separated by a $2 \mathrm{~m}$-thick interface layer) which was broadly evident from almost all investigated parameters (including, among others, the particulate matter and the total ion content, as well as the $\delta \mathrm{D}$ and $\delta^{18} \mathrm{O}$ values). This feature being mainly characterized by comparably higher isotope values and ion concentrations in the top section (also associated with a higher variability) and a change in the insoluble matter assemblage (likely made up by cryocalcite) point to a substantial change in the ice-formation process in the past. As probably forced by climate change this finding deserves prime attention, whereas the water isotope record remains questionable in carrying a genuine temperature signal.
Therefore future emphasis should be on detailed investigations of the principal ice-accumulation process, though, the co-isotope evaluations of the ERW core data proved slow freezing of drip water to be the main process. Such studies would greatly help to better understand the surprisingly highfrequency variability as well as the systematic changes seen in the total ion content (salt exclusion), cryocalcite abundance and the water isotope signature. First of all, this calls for drip-water sampling aimed at analyzing the seasonality with respect to discharge and isotope signature. Secondly, probing the ice surface between the core site and the drip water position may give insight into the spatial changes of the isotope values (and total ion content) which may possibly be connected to successive freeze-on events along the water flow line.

Acknowledgements. This work would not have been possible without the generous offer by Thomas Stocker to lend us the dedicated drill of the Physical Institute, University Bern, and without the technical/logistical support of the Eisriesenwelt Company. We greatly acknowledge the enormous efforts provided by the drilling crew and particularly by our chief driller Heinrich Rufli. Special thanks also go to the ERW guide Alois Rettenbacher for invaluable advice and support and to Phil Stricker for his commitment in the whole drilling campaign. We also wish to thank F. Obleitner for providing us with his ERW data on ice level changes and ice/rock temperatures. The work was partly financed by the Austrian Academy of Science through the AUSTRO*ICE*CAVES*2100 project.

Edited by: M. Luetscher

\section{References}

Achleitner, A.: Zum Alter des Höhleneises in der EisgrubenEishöhle im Sarstein (Oberösterreich), Die Höhle, 46, 1-5, 1995.

Andreichuk, V. and Dorofeev, E.: The influence of natural and anthropogenous factors on temperature regime and ice formations of Kungur Cave (Russia), Theor. Appl. Karstology, 7, 149-153, 1994.

Austrian Network of Isotopes in Precipitation (ANIP), Umweltbundesamt, http://www.umweltbundesamt.at/umweltinformation/ wasser/isotopen/isotopen, last access: 01.01.2011, 2010.

Behm, M. and Hausmann, H.: Eisdickenmessungen in alpinen Höhlen mit Georadar, Die Höhle, 58, 3-11, 2007.

Behm, M., Dittes, V., Greilinger, R., Hartmann, H., Plan, L., and Sulzbacher, D.: Decline of cave ice - a case study from the Austrian Alps (Europe) based on 416 years of observation, in: Proc. 15th Intern. Congr. Speleol., Kerrville, Texas, 19-26 July, 3, 1413-1416, 2009.

Bock, H.: Mathematisch-physikalische Untersuchung der Eishöhlen und Windröhren, in: Die Höhlen im Dachstein, edited by: Bock, H., Lahner, G., and Gaunersdorfer, G., Verein für Höhlenkunde in Österreich, 102-144, 1913.

Büntgen, U., Frank, D. C., Nievergelt, D., and Esper, J.: Summer temperature variations in the European Alps, A.D. 755-2004, J. Climate, 19, 5606-5623, 2006. 
Carte, A. E.: Air bubbles in ice, Proc. Phys. Soc., 77, 757-768, 1961.

Clausen, H. B., Vrana, K., Hansen, S. B., Larsen, L. B., Baker, J., Siggaard-Andersen, M-L., Sjolte, J., and Lundholm, S. C.: Continental ice body in Dobsina ice cave (Slovakia) - Part 2: Results of chemical and isotopic study, in: Proc. 2nd Int. Workshop on Ice Caves, Demänovská Dolina, Slovak Republic, 8-12 May, 2006, 29-37, 2007.

Dickfoss, P. V., Betancourt, J. L., Thompson, L. G., Turner, R. M., and Tharnstrom, S.: History of ice at Candelaria Ice Cave, New Mexico, New Mexico Bureau of Mines and Mineral Resources Bulletin, 156, 91-112, 1997.

Frank, D. and Esper, J.: Temperature reconstructions and comparisons with instrumental data from a tree-ring network for the European Alps, Int. J. Climatol., 25, 1437-1454, 2005.

Fröhlich, K., Kralik, M., Papesch, W., Rank, D., Scheifinger, H., and Stichler, W.: Deuterium excess in precipitation of Alpine regions - moisture recycling, Isotop. Environ. Health. Stud, 44(1), 61-70, 2008.

Gat, J. R.: Oxygen and hydrogen isotopes in the hydrologic cycle, Annu. Rev. Earth Planet. Sci., 24, 225-262, 1996.

Von Grafenstein, U., Erlenkeuser, H., Brauer, A., Jouzel, J., and Johnsen, S. J.: A mid-European decadal isotope-climate record from 15000 to 5000 years BP, Science, 284, 1654-1657, 1999.

Haeberli, W., Frauenfelder, R., Kääb, A., and Wagner, S.: Characteristics and potential significance of "miniature ice caps" (crestand cornice-type low-latitude ice archives), J. Glaciol., 50(168), 129-136, 2004.

Hauser, E. and Oedl, R.: Die große Eishöhle im Tennengebirge (Salzburg): Eisriesenwelt - V. Eisbildungen und meteorologische Beobachtungen, Speläol. Jb., 4, 17-47, 1922.

Hauser, E. and Oedl, R.: Eisbildungen und meteorologische Beobachtungen, in: Die Eisriesenwelt im Tennengebirge (Salzburg), 6, edited by: Angermayer, E., Asal, A., CzörnigCzernhausen, W., Hauser, E., Lehmann, O., Oedl, R., Pia, J., and Wettstein-Westersheim, O., Speläol. Monogr., Verlag Speläol. Inst., Wien, Österreich, 77-105, 1926.

Hausmann, H. and Behm, M.: Application of ground penetrating radar (GPR) in Alpine ice caves, The Cryosphere Discuss., 4, 1365-1389, doi:10.5194/tcd-4-1365-2010, 2010.

Holmlund, P., Onac, B. P., Hansson, M., Holmgren, K., Mörth, M., Nyman, M., and Perşoiu, A.: Assessing the palaeoclimate potential of cave glaciers: the example of the Scărişoara Ice Cave (Romania), Geografiska Annaler, 87A, 193-201, 2005.

Hubbard, B.: Freezing-rate effects on the physical characteristics of basal ice formed by net adfreezing, J. Glaciol., 37(127), 339347,1991

Jouzel, J. and Souchez, R. A.: Melting-refreezing at the glacier sole and the isotopic composition of the ice, J. Glaciol., 28(98), 3542, 1982.

Kern, Z., Molnár, M., Svingor, É., Perşoiu, A., and Nagy, B.: Highresolution, well-preserved tritium record in the ice of Bortig Ice Cave, Bihor Mountains, The Holocene, 19, 729-736, 2009.

Kern, Z., Fórizs, I., Molnár, M., Nagy, B., and Pavuza, R.: Isotope hydrological studies on the perennial ice deposit of Saarhalle, Mammuthöhle, Dachstein Mts, Austria, The Cryosphere Discuss., 4, 1449-1465, doi:10.5194/tcd-4-1449-2010, 2010.

Killawee, J. A., Fairchild, I. J., Tison, J.-L., Janssens, L., and Lorrain, R.: Segregation of solutes and gases in experimen- tal freezing of dilute solutions: implications for natural glacial systems, Geochimica et Cosmochimica Acta, 62(23-24), 36373655, 1998.

Klappacher, W. and Haseke-Knapczyk, H.: Salzburger Höhlenbuch, 4, Landesverein für Höhlenkunde in Salzburg, 556pp., 1985.

Lehmann, O.: IV. Morphologische Beobachtungen, Speläol. Jb., 3, 51-121, 1922.

Lehmann, M. and Siegenthaler, U.: Equilibrium oxygen- and hydrogen-isotope fractionation between ice and water, J. Glaciol., 37(125), 23-26, 1991.

Liebl, J., Avalos Ortiz, R., Golser, R., Handle, F., Kutschera, W., Steier, P., and Wild, E. M.: Studies on the preparation of small ${ }^{14} \mathrm{C}$ samples with an RGA and ${ }^{13} \mathrm{C}$-enriched material, Radiocarbon, 52-53, 1394-1404, 2010.

Luetscher, M.: Processes in ice caves and their significance for paleo-environmental reconstructions, $\mathrm{PhD}$ thesis, Universität Zurich, 2005.

Luetscher, M., Bolius, D., Schwikoswski, M., Schotterer, U., and Smart, P. L.: Comparison of techniques for dating of subsurface ice from Monlesi ice cave, Switzerland, J. Glaciol., 53, 374-384, 2007.

Mais, K. and Pavuza, R.: Hinweise zu Höhlenklima und Höhleneis in der Dachstein-Mammuthöhle (Oberösterreich), Die Höhle, 51, 121-125, 2000.

Mangini, A., Spötl, C., and Verdes, P.: Reconstruction of temperature in the Central Alps during the past 2000 years from a $\delta^{18} \mathrm{O}$ stalagmite record, Earth Planet. Sci. Lett., 235, 741-751, 2005.

Mangini, A., Verdes, P., Spötl, C., Scholz, D., Vollweiler, N., and Kromer, B.: Persistent influence of the North Atlantic hydrography on Central European winter temperature during the last 9000 years, Geophys. Res. Lett., 34, L02704, doi:10.1029/2006GL028600, 2007.

May, B.: Radiocarbon microanalysis on ice impurities for dating of Alpine glaciers, PhD thesis, Universität Heidelberg, 2009.

Obleitner, F. and Spötl, Ch.: The mass and energy balance of ice within the Eisriesenwelt cave, Austria, The Cryosphere Discuss. 4, 1741-1779, doi:10.5194/tcd-4-1741-2010, 2010.

Oerlemans, J.: Extracting a climate signal from 169 glacier records, Science, 308, 675-677, 2005.

Ohata, T., Furukawa, T., and Higuchi, K.: Glacioclimatological study of perennial ice in the Fuji ice cave, Japan. Part 1: Seasonal variation and mechanism of maintenance, Arctic Alpine Res., 26, 227-237, 1994a.

Ohata, T., Furukawa, T., and Osada, K.: Glacioclimatological study of perennial ice in the Fuji ice cave, Japan. Part 2: Interannual variation and relation to climate, Arctic Alpine Res., 26, 238244, 1994b.

Pavuza, R.: Updated data on ice development in some Austrian caves, 4th Intern. Workshop on Ice Caves, Obertrau, Austria, 511 June 2010, Abstract Volume, 28, 2010.

Pavuza, R. and Mais, K.: Aktuelle höhlenklimatische Aspekte der Dachstein-Rieseneishöhle, Die Höhle, 50, 126-140, 1999.

Pavuza, R. and Spötl, C.: Neue Forschungsergebnisse aus der Hundalm-Eishöhle (1266/1), Höhlenkundliche Mitteilungen Landesverein für Höhlenkunde Tirol, 38, 3-10, 2000.

Perşoiu, A., Onac, B., and Feurdean, A.: Multi-proxy climatic and environmental record for the last 1000 years in the western Carpathians, Romania, 4th Intern. Workshop on Ice Caves, Obertrau, Austria, 5-11 June 2010, Abstract Volume, 29, 2010. 
Racoviţă, G. and Onac, B. P.: Scărişoara glacier cave, in: Monographic study, Editura Carpatica, Cluj-Napoca, 140pp., 2000.

Reimer, P. J., Brown, T. A., and Reimer, R. W.: Discussion: reporting and calibration of post-bomb ${ }^{14} \mathrm{C}$ data, Radiocarbon, 46-3, 1299-1304, 2004.

Saar, R.: Eishöhlen - ein meteorologisch-geophysikalisches Phänomen, Geografiska Annaler, 38, 1-63, 1956.

Scheidleder, A., Boroviczeny, F., Graf, W., Hofmann, T., Mandl, G., Schubert, G., Stichler, W., Trimborn, P., and Kralik, M.: Pilotprojekt "Karstwasser Dachstein", Band 2: Karsthydrologie und Kontaminationsrisiko von Quellen, Umweltbundesamt Österreich, Monogr., Band 108, 1-155, 2001.

Souchez, R. A. and de Groote, J. M.: $\delta \mathrm{D}$-and $\delta^{18} \mathrm{O}$ relationships in ice formed by subglacial freezing: Paleoclimatic implications, $\mathrm{J}$. Glaciol., 31(109), 369-372, 1985.

Spötl, C.: Kryogene Karbonate im Höhleneis der Eisriesenwelt, Die Höhle, 59, 26-36, 2008.

Spötl, C. and Vennemann, T.: Continuous-flow IRMS analysis of carbonate minerals, Rapid Comm. Mass Spectr., 17, 1004-1006, 2003.
Steier, P., Drosg, R., Fedi, M., Kutschera, W., Schock, M., Wagenbach, D., and Wild, E. M.: Radiocarbon determination of particulate organic carbon in non-temperated, Alpine glacier ice, Radiocarbon, 48, 69-82, 2006.

Stoffel, M., Luetscher, M., Bollschweiler, M., and Schlatter, F. Evidence of NAO control on subsurface ice accumulation in a 1200 yr old cave-ice sequence, St. Livres ice cave, Switzerland, Quat. Res., 72, 16-26, 2009.

Vrana, K., Baker, J., Clausen, H. B., Hansen, S. B., Zelinka. J., Rufli, H., Očkaik, L. and Janočko, J.: Continental ice body in Dobsina ice cave (Slovakia) - Part 1. Project and sampling phase of isotopic and chemical study, Proc. 2nd Int. Workshop on Ice Caves, Demänovská Dolina, Slovak Republic, 8-12 May 2006, 24-28, 2007.

Wimmer, M.: Eis- und Lufttemperaturmessungen im SchönbergHöhlensystem (1626/300) und Modellvorstellungen über den Eiszyklus, Die Höhle, 59, 13-25, 2008.

Yonge, C. J. and MacDonald, W. D.: The potential of perennial cave ice in isotope palaeoclimatology, Boreas, 28, 357-362, 1999.

Žák, K., Onac, B. P., Perşoiu, A.: Cryogenic carbonates in cave environments: A review, Quat. Int., 187, 84-96, 2008. 